\title{
Biomass and Diversity of Soil Mite Functional Groups Respond to Extensification of Land Management, Potentially Affecting Soil Ecosystem Services
}

\author{
G. Arjen de Groot ${ }^{1 *}$, Gerard A. J. M. Jagers op Akkerhuis ${ }^{1}$, Wim J. Dimmers ${ }^{1}$, \\ Xavier Charrier ${ }^{2}$ and Jack H. Faber ${ }^{1}$
}

${ }^{1}$ Alterra-Wageningen UR, Wageningen, Netherlands, ${ }^{2}$ INRA-UE FERLUS, Lusignan, France

\section{OPEN ACCESS}

Edited by:

Maria Tsiafouli,

Aristotle University of Thessaloniki,

Greece

Reviewed by:

Paul John Hunter,

University of Warwick, UK

Martine Kos,

Netherlands Institute of Ecology,

Netherlands

${ }^{*}$ Correspondence:

G. Arjen de Groot

g.a.degroot@wur.nl

Specialty section:

This article was submitted to Agroecology and Land Use Systems,

a section of the journal

Frontiers in Environmental Science

Received: 30 October 2015

Accepted: 25 February 2016

Published: 15 March 2016

Citation:

de Groot GA, Jagers op Akkerhuis GAJM, Dimmers WJ, Charrier $X$ and Faber JH (2016) Biomass and Diversity of Soil Mite

Functional Groups Respond to Extensification of Land Management, Potentially Affecting Soil Ecosystem

Services. Front. Environ. Sci. 4:15.

doi: 10.3389/fenvs.2016.00015
Soil mites (Acari) are ubiquitous in soil ecosystems and show a vast taxonomic diversity with a wide range of life history characteristics and feeding strategies. Various taxa contribute directly or indirectly to soil processes, including nutrient cycling, soil formation and pest control. Mites thus support important ecosystem services of soils. Yet, their community composition, and therewith service provisioning, may differ between for instance intensively managed agricultural soils and extensively managed grassland soils. We therefore hypothesized that successional changes in the abundance and diversity of soil mite functional groups (feeding types) will occur following a conversion of arable land to grassland, affecting their contribution to ecosystem services. To test this, we studied the succession of mite communities on two Long Term Observatories (LTOs) in Lusignan (France) and Veluwe (the Netherlands). At Lusignan, sampling involved four combinations of recent and historic land use types. At the Veluwe, samples were taken in a secondary succession chronosequence in grasslands, representing a time frame up to 29 years after the conversion from arable land to grassland. Biodiversity and biomass were higher in grassland than in arable land, especially for the total mite community, the predators and the main taxa aiding in decomposition. After conversion of grassland to arable land, or vice versa, both taxon richness and biomass rapidly developed towards the prevailing conditions. Our results indicated that the taxon richness and biomass of the total mite community in grassland still continued to increase up to 29 years after the conversion from arable land to grassland. Total taxon richness increased with time since conversion, which was mainly due to the immigration of decomposers and predators. The biomass of different feeding guilds increased at variable speeds. The observed changes imply an increase in nutrient cycling and in the suppression of some potential pests. We discuss the relevance of these ecosystem services in extensively managed grasslands and agricultural systems. Furthermore, our results suggest that in agricultural rotational schemes that include one or more years of grassland, mite communities and associated ecosystem services may be partially, but not completely, restored to the conditions of long term grassland.

Keywords: Acari, functional diversity, ecosystem services, secondary succession, pest control 


\section{INTRODUCTION}

The average soil contains a huge taxonomic diversity of bacteria, protozoa, fungi, nematodes, enchytraeids, insect larvae, and earthworms. With their activity, all these organisms contribute to processes in the soil, either directly, for example through the digestion of plant roots or fungal hyphae, or indirectly, through the dispersal of bacteria and/or fungal spores. Viewing the process of ecosystem engineering as any physical transformation in the environment that modifies the resources for other organisms (Jones et al., 1994), soil invertebrates mediate soil functioning through a wide range of engineering processes. Examples of such processes are the redistribution of organic matter, bioturbation, the comminution, and incorporation of litter into soil, contributions to structural porosity and the formation of soil aggregates through burrowing, casting and nesting activities and the feeding on microbial communities (Freckman et al., 1997; Lavelle et al., 2006; Barrios, 2007; Brussaard et al., 2007).

Through these activities, soil invertebrates contribute in a significant way to the delivery of ecosystem services by soils (Wall et al., 2010; De Vries et al., 2013). By influencing the interactions that develop among soil physical, chemical and biological processes, they particularly affect what in the Millennium Ecosystem Assessment (Millennium Ecosystem Assessment Panel, 2005) are viewed as "regulating" or "supporting" services. Important examples of such services (Haines-Young and Potschin, 2013) are the control of pest and diseases, the decomposition of organic matter and the resulting nutrient cycling and soil formation.

A large body of studies has led to the general realization that highly intensive agricultural practices may strongly impact belowground biodiversity (e.g., Tsiafouli et al., 2015) and may have detrimental effects on intermediateecosystem services, such as pest control, decomposition and nutrient cycling (Foley et al., 2005; Millennium Ecosystem Assessment Panel, 2005; Kremen and Miles, 2012). Via the agri-enviromental schemes under the EU's Common Agricultural Policy (CAP) farmers can receive support and funding to apply a less intensive management, e.g., by transforming part of their land into extensively managed grasslands. Yet, while long-term grasslands are known to show relatively high biodiversity and ecosystem services like nutrient cycling, there is a general lack of longterm studies showing whether and when service provision is enhanced following a transition to extensively managed grassland (Horrocks et al., 2014). A clear time lag may exist between the management change and the arrival of stable microbial communities (Buckley and Schmidt, 2001) and increases in nutrient cycling efficiency (e.g., Horrocks et al., 2014, 2016). Effects on soil metazoa may strongly differ per taxonomic group. Within 3 years after grassland restoration, Postma-Blaauw et al. (2012) observed the recovery of a diverse nematode community but an only partial restoration of the species richness of predatory mites and negative effects on enchytraeid worms. More extensive studies are required to study effects in these groups on abundance and taxon diversity over longer periods of time.
This study focuses on soil mites, which are ubiquitous in soil ecosystems and show a vast taxonomic diversity with a wide range of life history characteristics and feeding habits. As a result, they are able to inhabit a broad range of habitats. Yet, they are known to show a negative association with the physical and chemical disturbances and low levels of organic matter that normally occur in agricultural soils (Petersen and Luxton, 1982; El Titi, 1984; Siepel and Van de Bund, 1988). After land management extensification, release from disturbance and a build-up in the amount, complexity and diversity of organic matter are expected to result in an increase of soil mite diversity with successional time (Bardgett and Shine, 1999; Maraun and Scheu, 2000). It has been shown that microarthropods are generally more abundant in soils of extensively managed systems, such as grasslands, than in intensively managed arable soils (Giller et al., 1997; Minor and Cianciolo, 2007; Postma-Blaauw et al., 2010). Likewise, taxon diversity has been shown to be higher in grasslands than in intensive arable lands (Menta et al., 2011), resulting in an overall higher soil biological quality. Here, we therefore hypothesized that the transition from an agricultural system to an extensively managed grassland will result in clear successional changes in the abundance and taxonomic composition of soil mite communities, and therewith in their contribution to ecosystem services.

The most studied service to which soil mites contribute concerns the decomposition of organic matter in the soil from roots and from other living or dead organic sources in the soil (Curry, 1969; Swift et al., 1979; Hågvar and Kjøndal, 1981; Neutel, 2001). This underlies the process of soil formation, as well as the flow of energy and nutrients to higher trophic levels (Koehler, 1999). Different feeding guilds of mites (Siepel and De Ruyter-Dijkman, 1993) contribute to these processes in different ways. An important contribution to the decomposition of organic matter is made by the fungivore and herbivore grazers. These guilds are capable of digesting cell wall material, and liberate nutrients from the recalcitrant cell wall material (Siepel and Maaskamp, 1994). A wider variety of mites contributes to soil formation, through burrowing, through the fragmentation of organic material, through the production of feces (e.g., Van Vliet and Hendrix, 2007; Culliney, 2013). The fragmentation of organic material and the production of feces are typically accounted for by the fungivore grazers and herbofungivore grazers (Siepel and Maaskamp, 1994). In addition, fungal grazers and browsers may, through their feeding activity play a role in increasing soil aggregate stability in former arable land (Seastedt, 1984; Duchicela et al., 2013). Based on these contributions, changes in the diversity and (relative) abundances of mite feeding guilds after a transition from arable land to grassland can be expected to impact soil formation and nutrient cycling.

A number of previous studies indicate that changes in land use can also affect the abundance and species composition of predatory mites. Postma-Blaauw et al. (2012) showed that in arable land the numbers, and the taxonomic diversity of mesostigmatid mites (which includes the predatory taxa) were low, while in grassland more taxa were found, and in higher numbers. Mite communities of long-term and new arable land were very much alike, whilst markedly different from 
those of long-term and new grasslands. The composition of mesostigmatid mites has also been found to clearly change with time since after a major land use change, for instance between young, mid-aged, and old fallows (Wissuwa et al., 2012) and in reclaimed power plant waste dumps (Madej and Stodółka, 2008). When combined, such results suggest a strong and immediate reducing effect of intensive soil treatment (e.g., plowing) and a slow succession from an arable related species composition to a long-term grass related species composition. In contrast to their low biomass, predatory mites can have a disproportionately high effect on matter flows in ecosystems (Moore and De Ruiter, 2000). Various taxa have been linked to pest control, either as natural predators (Afifi and Van der Geest, 1984; Koehler, 1999; Menzler-Hokkanen, 2006) or as inoculation biocontrol agents for e.g., bulb mites, thrips, and endoparasitic nematodes (Bennison et al., 2002; Gerson et al., 2003).

Despite of these general insights, only limited knowledge is available on the variation in the presence of different functional groups of mites across soils that are subjected to different management types. Even less is known about how the presence of these groups change following land use changes, and how this affects the provision of ecosystem services. Additional insights in these respects will improve our ability to optimize agricultural practice by making use of the natural diversity available in soils. In this study, we made use of the experimental set-ups available from two Long Term Observatories (LTOs), to observe successional patterns in soil mite communities (a) after a recent conversion of arable land to grassland, while taking historic land use into account, and (b) in a chronosequence of grasslands that differed in the period since conversion from arable practice. We assessed the (rate of) change in both abundance and taxonomic richness in the total community, as well as in various functional groups (feeding guilds), in order to derive hypotheses on the potential effect of a change in land use from arable land tot grassland on soil functioning and associated ecosystem services.

\section{MATERIALS AND METHODS}

\section{Site Description}

The experimental results originate from two long-term observatory sites (LTO's) which have been part of the EU programme Ecofinders: Veluwe (the Netherlands) and Lusignan (France).

The SOERE "Agro-ecosystems, biogeochemical cycles and biodiversity" (ACBB) Lusignan experiment (INRA PoitouCharentes, 2015) has been set up as a block design, consisting of four blocks, each subdivided in multiple fields. In three periods between 1996-2000, 2001-2004, and 2005-2011 the fields were cultivated in the following way: 1. permanent arable fields (AAA), 2. arable lands converted to grassland 7 years before sampling (AAG), 3. grasslands that were converted to arable land for 4 years, after which they were converted again to grassland 7 years before sampling (GAG), and 4. Grasslands which were converted to arable land and remained arable land during the 11 years before sampling (GAA). A schematic overview of the land use history per block is presented in Figure S1.
The Veluwe LTO site included nine fields at different locations. All the fields were situated on sandy soils with similar characteristics, and had been in use as arable land in the past. Arable fields were converted to grassland at different points in time (varying from 6 to 29 years before the moment of sampling; see Table 1) and represent a chronosequence of fields with different successional ages.

\section{Sampling and Identification}

Each of the four land use history types at the Lusignan LTO was represented by two replicate fields. Four soil cores were sampled in each field (summed surface of $105,58 \mathrm{~cm} 2$, depth from 0 to $-10 \mathrm{~cm}$ ) and the extracted mites were pooled into one sample per field. In this way a total of eight samples was obtained representing four land use combinations times two replicates.

At the Veluwe LTO, three plots were randomly located in each of the nine fields of the chronosequence. In each plot, a soil core was sampled (surface $26.42 \mathrm{~cm} 2$, depth from 0 to $-10 \mathrm{~cm}$ ) which was separately extractedfor mites. In total, 27 (nine times three) samples were collected.

Soil cores were obtained with the help of a split-corer, filled from top to bottom with $2.5 \mathrm{~cm}$ high plastic rings (according to ISO standard 23611-2-2006; ISO, 2006). The diameter and depth of a sample was $5.8 \mathrm{~cm}$ and $10 \mathrm{~cm}$ (four rings), respectively. The volume of a sample was $264.2 \mathrm{cc}$. The samples were transported to the lab in the PVC rings in PVC tubes closed with lids on the bottom and top, while kept in a cool-box. The mesofauna was extracted by means of Tullgren extraction for 7 days (ISO, 2006). A two-step extraction was used, with a 3-days initial temperature of $28^{\circ} \mathrm{C}$ and a subsequent 4 -days period of $45^{\circ} \mathrm{C}$, using a heat generating carbon wire light bulb $(60 \mathrm{~W})$. The obtained micro-arthropod communities of the three samples per plot were pooled, and stored in $97 \%$ ethanol.

A standardized gel-based subsampling method (Jagers op Akkerhuis et al., 2008) was used to identify a random subsample of 150 individual mites per pooled sample. Taxon identification was based on (Weigmann, 2006) for Cryptostigmata (Oribatida), (Karg, 1989), Karg (1993) for Mesostigmata, Krantz and Walter

TABLE 1 | Site characteristics for the nine fields of the Veluwe LTO chronosequence, with respect to location (UTM coordinates) and successional age: the year of conversion to grassland, and between brackets the number of years between the conversion and sampling for this study.

\begin{tabular}{llll}
\hline Site name & Latitude & Longitude & $\begin{array}{c}\text { Year of } \\
\text { conversion }\end{array}$ \\
\hline Dennenkamp & $52^{\circ} 01^{\prime} 44.5894^{\prime \prime}$ & $005^{\circ} 48^{\prime} 03.5091^{\prime \prime}$ & $1982(29)$ \\
Mosselsche Veld & $52^{\circ} 04^{\prime} 24.2422^{\prime \prime}$ & $005^{\circ} 44^{\prime} 13.9967^{\prime \prime}$ & $1985(26)$ \\
Wolfheze & $51^{\circ} 59^{\prime} 47.7078^{\prime \prime}$ & $005^{\circ} 47^{\prime} 37.1111^{\prime \prime}$ & $1988(23)$ \\
Nieuw Reemst & $52^{\circ} 02^{\prime} 34.1978^{\prime \prime}$ & $005^{\circ} 46^{\prime} 29.5062^{\prime \prime}$ & $1990(21)$ \\
Mossel & $52^{\circ} 03^{\prime} 39.1373^{\prime \prime}$ & $005^{\circ} 45^{\prime} 06.8209^{\prime \prime}$ & $1995(16)$ \\
Loenen & $52^{\circ} 04^{\prime} 32.3026^{\prime \prime}$ & $005^{\circ} 57^{\prime} 41.2815^{\prime \prime}$ & $1999(12)$ \\
Telefoonweg & $52^{\circ} 00^{\prime} 08.7991^{\prime \prime}$ & $005^{\circ} 45^{\prime} 11.0326^{\prime \prime}$ & $2002(9)$ \\
Oud Reemst & $52^{\circ} 02^{\prime} 26.0863^{\prime \prime}$ & $005^{\circ} 48^{\prime} 35.9526^{\prime \prime}$ & $2005(6)$ \\
Reyerscamp & $52^{\circ} 01^{\prime} 00.1854^{\prime \prime}$ & $005^{\circ} 46^{\prime} 21.3066^{\prime \prime}$ & $2005(6)$
\end{tabular}


(2009) for Prostigmata and Hughes (1976) for Astigmata. Identification up to species level was attempted. Within some taxonomic groups, however, juveniles lack sufficient (known) morphological discriminatory characters. Such juvenile individuals could only be identified to genus or family level.

\section{Biomass Calculations}

Body length, width and height were measured for multiple specimens per taxon, available from our reference collection. Average sizes were calculated per taxon. For eight taxa we had no reference specimens and body sizes were obtained from the literature: Ceratozetes minutissimus, Lucoppia burrowsi, Ameroseius corbiculus, Amerobelba decedens, Oppiella falcata, Protoribates capucinus (Gil-Martín and Subias, 1998; Bruin et al., 1999; Murvanidze and Weigmann, 2003; Simsek and Baran, 2012; Jamshidian et al., 2015). Based on the body measurement data, the volume of "an average individual" was calculated for each taxon, assuming an ellipsoid shape for mites. A density of $1.1 \mathrm{~g} / \mathrm{cm}^{3}$ was assumed for all taxa (pers. comm. Prof. Dr. H. Siepel). Based on the calculated densities per square meter, the total biomass was calculated per taxon per area $(\mathrm{g} / \mathrm{ha})$.

\section{Statistical Analysis}

Biomass and species richness were calculated for the total mite community per plot, as well as per feeding guild. Based on definitions by Siepel and De Ruyter-Dijkman (1993), we distinguished six main feeding guilds: bacteriovores, fungivores, herbofungivores, herbivores, predators, and omnivores. As physiological studies by Siepel and De Ruyter-Dijkman (1993) indicated marked differences between grazers and browsers, the fungivore and herbofungivore strategies were split into two subgroups. Fungivore and herbofungivore grazers can digest fungal cell walls, a property that is relevant for the decomposition of organic material (Siepel and Maaskamp, 1994). Therefore, an additional group was created in which the fungivore grazers and herbofungivore grazers were jointly named "main decomposers," for which group separate values were calculated for the biomass and taxon richness (as a measure of diversity). Classification of mite taxa into the abovementioned groups was based on a database available at Alterra, established based on taxonomic information in combination with the broad range of ecological literature about feeding habits (e.g., Bhattacharyya, 1962; Hartenstein, 1962; Karg, 1962; Ito, 1971; Luxton, 1972).

For the Lusignan LTO, we tested for differences in both biomass and taxon richness per feeding guild using linear mixed models in SPSS version 22 (IBM corp.), with land use treatment as categorical fixed variable and block as random variable. With respect to taxon richness, we only analyzed differences for the six main feeding guilds, since a further differentiation resulted in too low numbers of taxa per group to produce valid statistics. In case of significant overall differences, LCD post-hoc tests were used to test for pairwise differences between treatments. Because we were mainly interested in the development of the mite community following a transition from arable land to grassland, and to reduce the number of pairwise comparisons, we focused on the differences between the fields that were converted to grassland but had different historic land use up to 11 years before our sampling event (AAG and GAG; see Section Site Description for exact code descriptions), and the difference between each of those and the permanent arable fields (AAG-AAA and GAG-AAA).

For the Veluwe LTO experiment, effects of time since the transition to grassland on biomass and taxon richness were also tested using linear mixed models in SPSS, using time since transition as a continuous fixed variable and site as random variable. For this experiment, biomass data per feeding guild were log transformed prior to all analyses to comply with assumptions for normality. We tested separate models for the total community and each of the feeding guilds (again restricting to the six main guilds with respect to taxon richness). In some cases where no significant linear relation was found, mite biomass or taxon richness seemed to converge to a certain maximum value. Therefore, in such cases we also tested an inverse regression model $\left(\mathrm{y}=\mathrm{b}_{0}+\mathrm{b}_{1} / \mathrm{x}\right)$ and an $\mathrm{S}$-curve regression model $\left(\ln (y)=b_{0}+b_{1} / x\right)$ via the curve estimation option in SPSS.

Differences in taxonomic composition among the nine fields of the Veluwe experiment, as well as among the fields with different land use treatments at Lusignan, were analyzed with the help of principle component analysis (PCA) in PCOrd (v.6.0; McCune and Mefford, 1999), based on presence/absence scores per taxon per site or field. To improve clarity in the PCA biplot for the Veluwe experiment, the fields were grouped in three classes of time since transition to grassland: recent, middle, and old. The following locations were associated with "recent": Oud Reemst (2005), Reyerscamp (2005), Telefoonweg (2002) and Loenen (1999). The following locations were associated with 'middle': Wolfhezerheide (1988), Mossel (1995), and Nieuw Reemst (1990). The following locations were associated with 'old': Mosselsche Veld (1985) and Dennenkamp (1982). For the Lusignan experiment, fields were grouped according to historical land use treatment.

\section{RESULTS}

\section{Lusignan Experiment}

Based on the multivariate analysis, the mite community responded in different ways to the four land use history types at the Lusignan LTO (Figure 1). Firstly, the fields grouped along the first axis according to the most recent land use type. That is, the composition of the four fields that were converted to grassland for the last 7 years was relatively similar (AAG and GAG), while their composition was different from that of the fields that were arable land for the last 11 or 16 years (AAA and GAA). Secondly, fields were split along the second axis according to their historic land use type (GAA vs. AAA and GAG vs. AAG). Thus, a past difference in land use type still resulted in a difference in species composition after 11 years of equal land use.

The above trends with cropping system and time after conversion were largely reflected in the data of taxon richness and biomass. The largest differences in taxon richness and biomass of the total mite community were observed between the fields that shared the historic land use as arable field, but were recently converted to either arable land or grassland (AAA-AAG; Figure 2, Table 2). When considering the various feeding guilds, the predators, the fungivores and the herbivore 


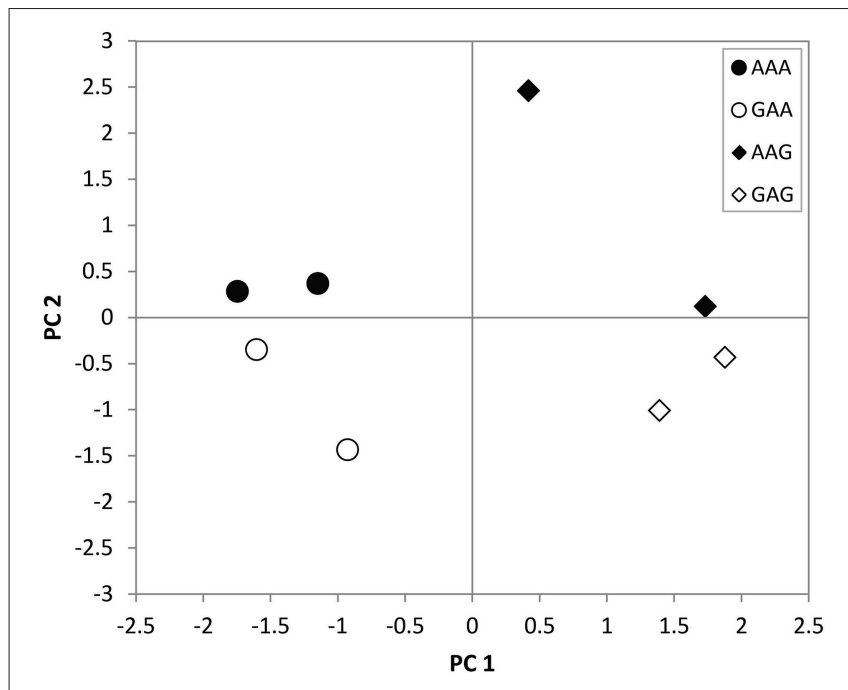

FIGURE 1 | PCA biplot showing the variation among the eight sampled fields at the Lusignan LTO (representing four land use treatments indicated by different symbols) along the first two axes of a principle component analysis, which together explain $58.8 \%$ of the total variation.

grazers showed a higher biomass in the fields that recently were converted into grasslands. For the predators, these differences were mostly explained by differences in the abundance of the general predators (Figure 3A). Amongst the fungivores, the fungal browsers showed a clear increase in biomass following conversion to grassland, while this increase was not significant for the fungal grazers (Figure 3B, Table 2). The group of main decomposers seemed to show a higher biomass in the recent grasslands (AAG and GAG) than in the recent arable lands (AAA and GAA) but this difference was insignificant due to large variation among the recent grassland plots (Figure S2, Table 2). Although in the multivariate analysis the recent grasslands (GAG and AAG) were separated from the other land use history types based on recent land use (indicating a difference in taxonomic composition), the biomass of the total community or of any specific feeding guild did not significantly differ between these land use history types (Table 2). Significant differences in taxon richness among any of the land use history types were found only for predators: arable fields recently converted into grassland showed a higher richness than permanent arable fields (Table 2).

\section{Veluwe Chronosequence}

The results of the multivariate analysis are shown in Figure 4. The variation among fields along the first axis is roughly in line with their age rank in the chronosequence. Recently converted fields clearly separated from the "old" grasslands. The middle plots showed a broad variation in species composition. The species composition of Mossel ranked between the old and new samples. However, the species compositions of NieuwReemst and Wolfheze did not comply with the general pattern of temporal succession. Variation along the second axis mainly concerned differences in taxonomic composition between the four recently converted fields. The "old" grasslands showed little variation along this axis.

Both the average biomass and taxon richness of the total mite community increased over time after conversion to grassland (Table 3, Figures 5A,B). When looking at individual functional groups, no linear increase was observed for the biomass of the predatory mites, but a significant inverse relation existed ( $d f=1$; $F=10.291 ; P=0.004)$, indicating a rapid increase in the first 510 years after the transition to grassland and slower development afterwards (Figure 5C). This relation was mainly accounted for by the general predators (significant inverse relation; $d f=1$; $F=12.125 ; P=0.002$ ), representing $83-98 \%$ of the total biomass of predatory mites (see Figure S3 for separate graphs for general, arthropod and nematode predators). A significant linear increase over time was found for the summed number of predatory taxa (Figure 5D). The biomass of all herbivores increased with time after conversion (Table 3), but this effect was almost entirely explained by a high biomass of one herbivore grazer (the oribatid mite species Platynothrus peltifer) in the oldest plot (Figure 5E). The herbivore browsers did not show a significant trend. The taxon richness of the herbivore community was relatively low in fields converted 6 years ago (Figure 5F), but remained stable from 10 years after the conversion onwards (significant inverse relation; $d f=1 ; F=21.108 ; P=0.003$ ). The biomass of all fungivores was only near significant $(P=0.069$; Table 3, Figure 5G). The reason for this was that this group combines the fungivore grazers, which significantly increased over time (Table 3), and the fungivore browsers, which showed highly variable results (see Figure S4). The taxon richness of the fungivore community did not significantly change over time (Figure 5H). The average biomass and number of taxa of the main decomposers was positively related with time since the transition to grassland (Figures 5I,J).

\section{DISCUSSION}

\section{Succession in Soil Mite Communities Following a Transition From Arable Land to Grassland}

Both the diversity and the composition of microarthropod species assemblages in soils are known to differ substantially with land use type, and will respond to changes in land management (Minor and Cianciolo, 2007). In a general study on microarthropods, Menta et al. (2011) showed taxonomic assemblages to be clearly different between grasslands and agricultural lands, a pattern that was largely driven by differences in the mites and springtails. A similar distinction was observed for soil mites by Dirilgen et al. (2015) across a north-south European transect. Moreover, microarthropods are less abundant in intensively managed arable soils than in soils of extensively managed systems, such as grasslands (Giller et al., 1997; PostmaBlaauw et al., 2010; Menta et al., 2011). Thus, the transition from an agricultural system to an extensively managed grassland can be expected to result in clear changes in the mite community of the soil. Indeed, the results from both our field experiments highlighted that changes in land use lead to marked changes 
A

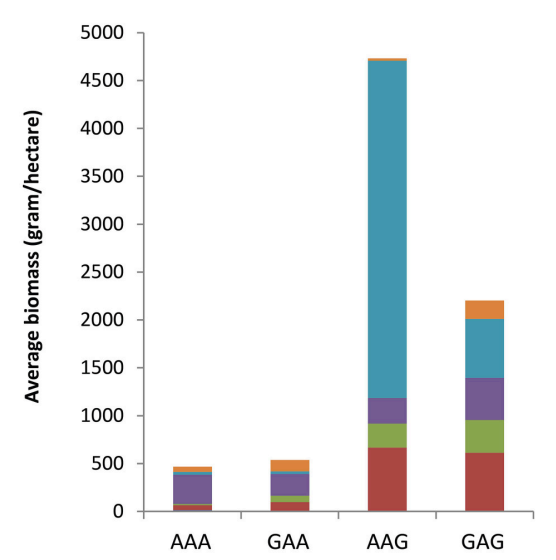

B

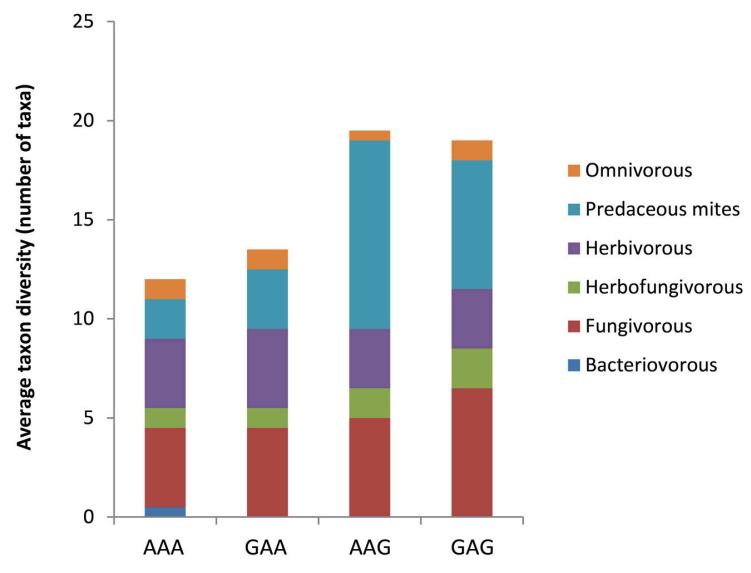

FIGURE 2 | Differences in average biomass (A) and taxon richness (B) between the four land use combinations at the Lusignan LTO, presented as stacked bars indicating contribution of the six main feeding guilds with different colors. AAA, permanent arable fields; GAA, grasslands that were converted to arable land and remained arable land during the 11 years before sampling; AAG, arable lands converted to grassland 7 years before sampling; GAG, grasslands that were converted to arable land for 4 years, after which they were converted again to grassland 7 years before sampling.
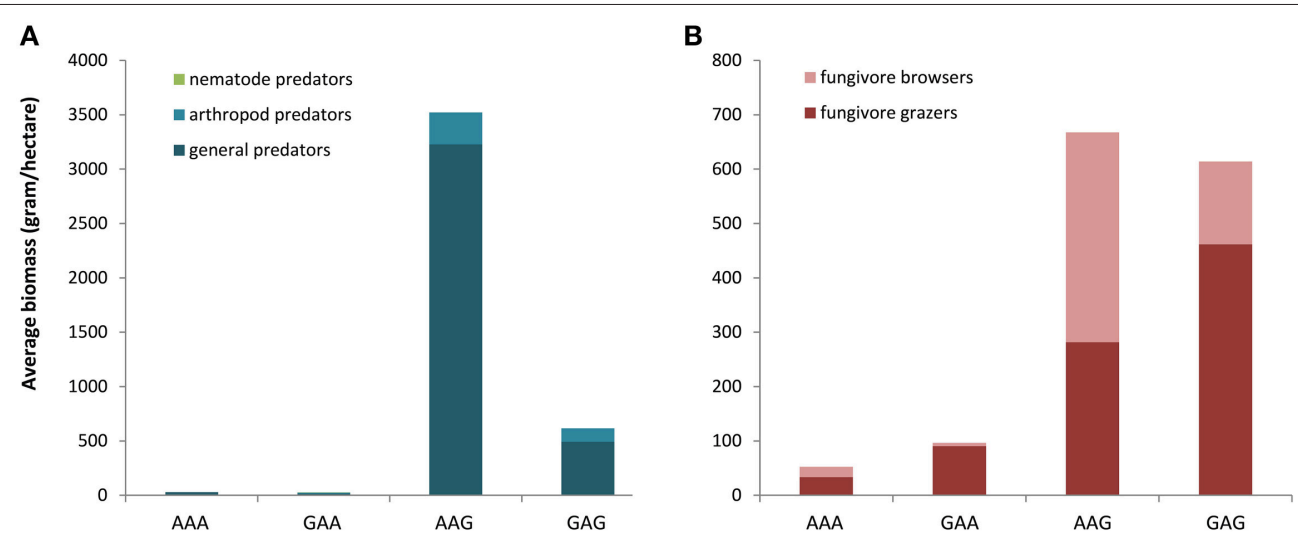

FIGURE 3 | Differences in average biomass of predatory mites (A) and fungivore mites (B) between the four land use combinations at the Lusignan LTO, presented as stacked bars indicating contribution of sub-groups within feeding guilds with different colors. AA, permanent arable land; AG, arable to grassland; GA, grassland to arable; GG, permanent grassland.

in taxonomic composition and increases in total biomass and number of taxa.

The multivariate analyses for the Lusignan dataset indicated that the composition of the mite community in recently converted fields was largely determined by the most recent land use type. This is perhaps not so surprising when considering conversion from grassland to arable soil, since a sudden application of tillage and agrochemicals will trigger important changes in the soil (Ingham, 1985; Cortet et al., 2002; Van Capelle et al., 2012). However, our results also show that grasslands develop a recognizable signature within 7 years after a transition from arable land use.

The difference in composition that still existed between fields that shared the same land use for the last 11 years but differed in land use before that time (Figure 1) indicates that land use has long-term consequences for the successional patterns of the local mite community. This does also fit with the observed differences in species composition along the chronosequence of early to late successional grasslands at the Veluwe LTO (Figure 3), where biomass and taxon richness continued to increase with the age of the grassland up to 29 years after the transition from arable land. This steady increase in richness was in line with a previous study by Kardol et al. (2009) for the same chronosequence. These results seem to be in contrast with those from the Lusignan experiment, where the biomass and number of taxa were largely determined by the recent shift to grassland, suggesting that they change markedly within the first years after the transition while no significant differences were observed between recent grasslands with a different historic land use type. This apparent rapid stabilization of the number of taxa may be related to higher possibilities for colonization, since here plots with different treatments were located closely 
TABLE 2 | Results of linear mixed models for the Lusignan LTO experiment, testing for differences in biomass and taxon richness per soil mite functional group between fields $(N=8)$ representing four different combinations of current and historical land use management.

\begin{tabular}{|c|c|c|c|c|c|c|c|}
\hline Variable & Group & $d f$ & $\boldsymbol{F}$ & $P$ & $A A A-G A G$ & AAA-AAG & GAG-AAG \\
\hline \multirow[t]{17}{*}{ Biomass } & All mites & 3 & 32.507 & 0.015 & & * & \\
\hline & Bacterivores & 3 & 1.000 & 0.535 & & & \\
\hline & All fungivores & 3 & 9.079 & 0.029 & * & * & \\
\hline & Fungivore grazers & 3 & 0.945 & 0.492 & & & \\
\hline & Fungivore browsers & 3 & 18.382 & 0.001 & * & * & \\
\hline & All herbofungivores & 3 & 9.513 & 0.066 & & & \\
\hline & Herbofungivore grazers & 3 & 2.831 & 0.156 & & & \\
\hline & Opp. herbofungivores & 3 & 2.527 & 0.196 & & & \\
\hline & All herbivores & 3 & 0.380 & 0.774 & & & \\
\hline & Herbivore grazers & 3 & 14.352 & 0.013 & ** & * & \\
\hline & Herbivore browsers & 3 & 1.191 & 0.419 & & & \\
\hline & All predators & 3 & 18.127 & 0.009 & * & $\star \star *$ & \\
\hline & General predators & 3 & 11.824 & 0.019 & * & * & \\
\hline & Arthropod predators & 3 & 93.837 & $<0.001$ & ** & $\star \star$ & \\
\hline & Nematode predators & 3 & 1.000 & 0.535 & & & \\
\hline & Omnivores & 3 & 1.415 & 0.362 & & & \\
\hline & Main decomposers & 3 & 15.887 & 0.060 & & & \\
\hline \multirow[t]{8}{*}{ Taxon richness (per sample) } & Total & 3 & 115.356 & 0.009 & & ** & \\
\hline & Bacterivores & 3 & 1.000 & 0.535 & & & \\
\hline & Fungivores & 3 & 3.467 & 0.202 & & & \\
\hline & Herbofungivores & 3 & 3.667 & 0.222 & & & \\
\hline & Herbivores & 3 & 3.667 & 0.121 & & & \\
\hline & Predators & 3 & 18.424 & 0.009 & & * & \\
\hline & Omnivores & 3 & 1.000 & 0.455 & & & \\
\hline & Main decomposers & 3 & 3.347 & 0.227 & & & \\
\hline
\end{tabular}

We present the result of the overall test between all four combination (df, F-value, and significance; bold text indicates significant difference at $P<0.05$ ), as well as results of pairwise

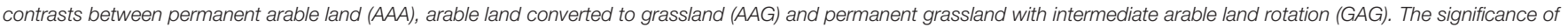
the pairwise differences (as tested via LSD post-hoc tests) is indicated via asterisks, as follows: ${ }^{*} P<0.05$; ${ }^{* *} P<0.01$.

together in blocks, which may speed up the arrival of even slow dispersing taxa. Dispersal from adjacent habitats may thus be a dominant factor determining the development of the number of mite taxa following the establishment of a grassland. Relatively limited dispersal distances may also explain the marked variation in composition between the four young successional grasslands at Veluwe LTO, which is in line with the optimum in beta-diversity during the first years after the land use transition reported by Kardol et al. (2009). It can be hypothesised that the taxonomic composition of a grassland will be strongly affected by random or spatial differences in identity of newly colonizing taxa, which might explain the observed initial variation among grasslands, while compositions might converge in later years with the arrival of additional species.

Successional changes with respect to both the identity and the number of taxa can also be related to the development of a vertical soil profile. In a study of secondary succession of wheat fields into beech wood, Scheu and Schulz (1996) for instance showed that in early successional stages oribatids predominantly colonized the litter layer, while in more developed beech woods the upper mineral soil was also colonized and actually more taxa were present in this soil layer. Finally, the stabilization of the taxon richness in combination with a continued succession in species composition may indicate that some mites species remain present in very low numbers in arable land, and increase in numbers when biotic and abiotic circumstances in grassland at different stages of succession have become favorable. More intense sampling at different spatial scales in arable lands may help to assess whether such "latent" populations of mites do indeed exist in arable lands. Well known abiotic changes in aging grasslands are e.g.,: a slow build-up of soil organic matter, an increase in total nitrogen, a decrease of the $\mathrm{pH}$, and a loss of phosphate (Van der Wal et al., 2006; Wissuwa et al., 2013). Inverse patterns in abiotic parameters have been observed after grassland was converted to arable land (Postma-Blaauw et al., 2012).

A detailed study of the functional diversity in soil organisms will allow a better understanding and better modeling of the interactions between management or environmental factors and ecosystem services (Duru et al., 2015). When studying functional diversity in terms of feeding guilds, our observations at Lusignan suggested that all major guilds were present even in intensively managed arable soils, despite yearly tillage and high nitrogen inputs. Grassland soils, however, showed much higher biomass of fungivore, herbivore and especially predatory mites. The 


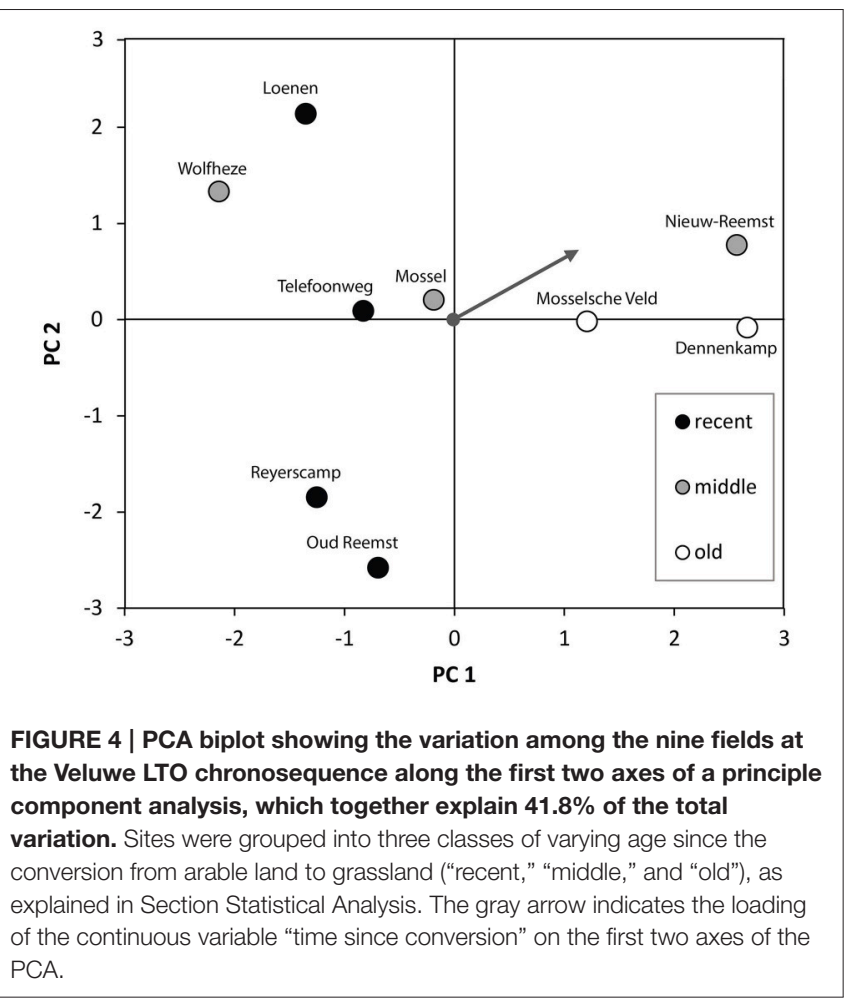

same guilds also responded in a significant way to time after conversion in the Veluwe chronosequence experiment, but the timing of the responses differed between guilds and between the biomass and taxon richness of these guilds. The observed patterns suggest that predatory mites are able to develop high abundances within 10 years after a conversion from arable land to grassland and that abundances are relatively stable afterwards, while additional taxa arrive with time, resulting in a steady increase in number of taxa. This is in contrast with the patterns observed for herbivores, of which the number of taxa stabilized already early in succession, while the abundances of the species kept increasing over time. The community of decomposers seems to develop relatively slowly both in terms of abundance and taxon richness. Herbofungivorous and fungivorous grazers typically are almost completely absent from high-input grasslands, and appear in high numbers in low-input grassland (Siepel, 1996). Many species in these groups have low population growth rates and low dispersal rates (Siepel, 1991, 1994), which might explain the observed slow increases in abundance and taxon richness.

\section{Implications of Our Results for Ecosystem Service Provision}

Additional studies, preferably using e.g., reciprocal transplantation and inoculation experiments to test which species arrive and survive under various conditions (e.g., Klimek and Rolbieki, 2014), will be needed to assess exactly which factors drive the observed differences in mite community composition among our study fields. Yet, when combining the results of the Lusignan and Veluwe experiments, we can deduct a few general trends in the abundance and taxon richness of particular mite
TABLE 3 | Results of Linear Mixed Models for the Veluwe LTO chronosequence, testing for the effect of time since conversion from arable land to grassland on mite biomass (per plot; $N=21$ ) and taxon richness (per site; $N=9$ ) in the total community as well as per feeding guild.

\begin{tabular}{|c|c|c|c|c|}
\hline Variable & Group & $d f$ & $\boldsymbol{F}$ & $P$ \\
\hline \multirow[t]{17}{*}{ Biomass } & All mites & 1 & 12.338 & 0.010 \\
\hline & Bacterivores & 1 & 0.120 & 0.739 \\
\hline & All fungivores & 1 & 4.612 & 0.069 \\
\hline & Fungivore grazers & 1 & 14.432 & 0.001 \\
\hline & Fungivore browsers & 1 & 0.405 & 0.545 \\
\hline & All herbofungivores & 1 & 2.861 & 0.135 \\
\hline & Herbofungivore grazers & 1 & 1.973 & 0.203 \\
\hline & Opp. herbofungivores & 1 & 1.633 & 0.242 \\
\hline & All herbivores & 1 & 12.042 & 0.010 \\
\hline & Herbivore grazers & 1 & 9.322 & 0.018 \\
\hline & Herbivore browsers & 1 & 0.793 & 0.403 \\
\hline & All predators & 1 & 4.425 & 0.073 \\
\hline & General predators & 1 & 4.665 & 0.068 \\
\hline & Arthropod predators & 1 & 1.647 & 0.240 \\
\hline & Nematode predators & 1 & 2.795 & 0.107 \\
\hline & Omnivores & 1 & 1.445 & 0.241 \\
\hline & Main decomposers & 1 & 8.195 & 0.024 \\
\hline \multirow[t]{8}{*}{ Taxon richness } & Total & 1 & 14.367 & 0.007 \\
\hline & Bacterivores & 1 & 0.513 & 0.497 \\
\hline & Fungivores & 1 & 4.608 & 0.069 \\
\hline & Herbofungivores & 1 & 3.120 & 0.121 \\
\hline & Herbivores & 1 & 4.190 & 0.080 \\
\hline & Predators & 1 & 3.138 & 0.001 \\
\hline & Omnivores & 1 & 1.034 & 0.319 \\
\hline & Main decomposers & 1 & 14.813 & 0.006 \\
\hline
\end{tabular}

Degrees of freedom (df), F-Value ( $F$ ), and test significance $(P)$ are given for each model. Significant effects $(P<0.05)$ are given in bold text.

feeding guilds during early and late succession after conversion from arable land to grassland. Using relations known from the literature (as outlined in the introduction), we can then derive hypotheses on the implications this may have for the ecosystem services of pest regulation, nutrient cycling and soil formation.

After conversion to grassland the biomass of predatory mites showed a rapid increase, while the number of taxa increased markedly in the first years, and continued to rise until later years. The limited number of predatory species in arable land may have been the result of a similarly low diversity of prey species and a few predatory species may still have a strong suppressing effect if abundant and selectively preying on a particular pest species (Straub, 2006). Yet, one can more generally expect that a higher taxonomic richness of predators would result in a higher potential to control a wide variety of pest species (Snyder and Straub, 2005) and thus a higher potential to suppress newly invading pests. In that sense, the potential for pest regulation in arable land was supposedly at a relatively low level, and developed quickly to higher levels in grassland, where it continued to slowly increase with time. 


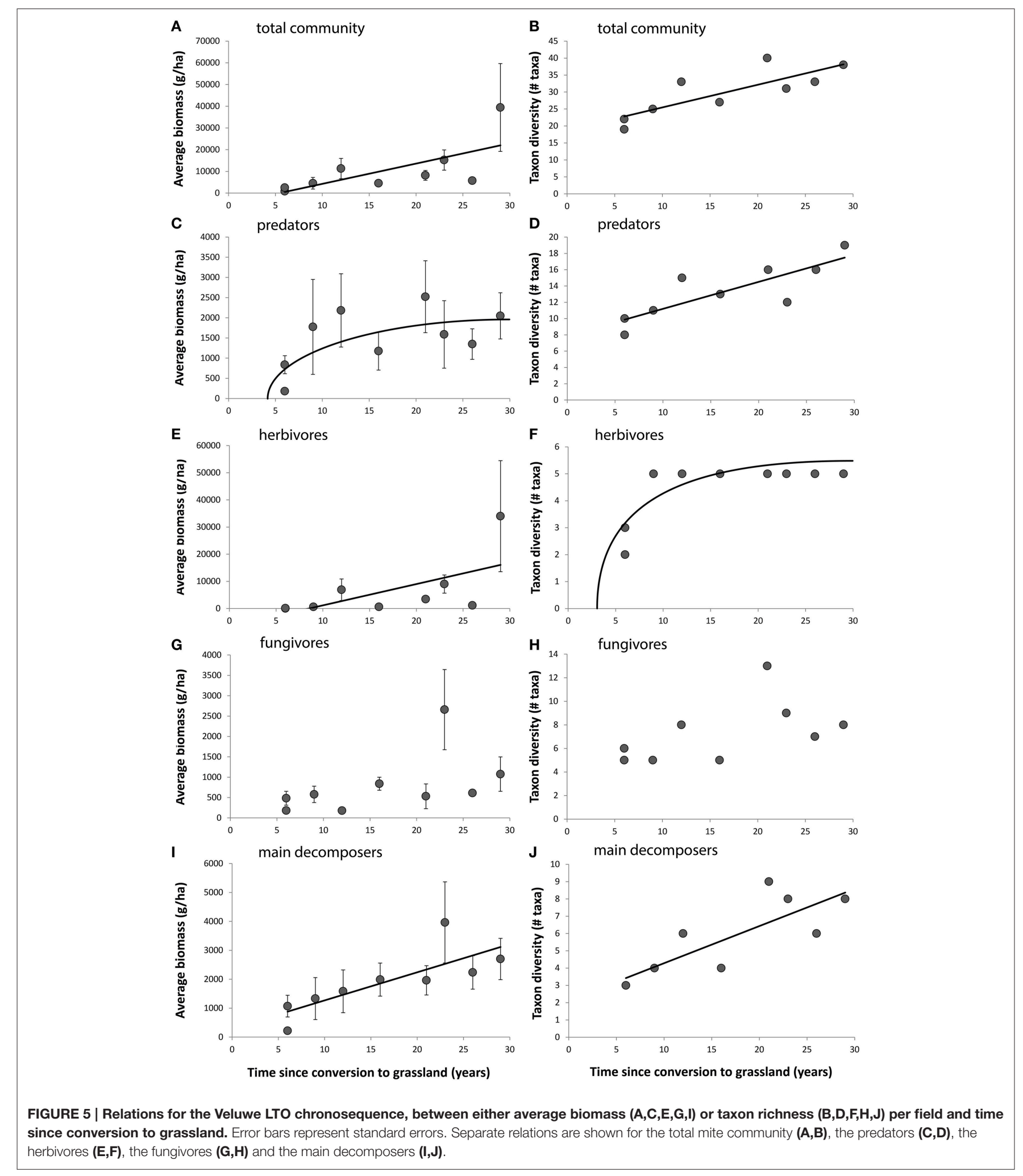

Soil formation depends on a broad palette of burrowing activities, fragmentation of organic material, the leaving behind of the cuticle of prey items, the grazing or browsing effects on fungal hyphae, and the production of feces (e.g., Van Vliet and
Hendrix, 2007). Because of the variety in processes involved, the concerted impacts of all the different mite species can likely best be represented by the total mite biomass. After conversion from arable land to grassland, the total mite biomass increased both 
on the short term (Lusignan) and on the long term (Veluwe). This indicates that the general contribution of soil mites to soil formation may be expected to increase over a long period after arable land has been converted to grassland.

Upon conversion to grassland, the biomasses of fungivores, herbivore grazers and main decomposers increased, both in the Lusignan rotation and in the Veluwe chronosequence. As the main decomposers feed on fungi or on plant roots, an increase in the biomass of these groups can be expected in environments with a thick organic layer and/or a high root biomass (Luxton, 1982; Maraun and Scheu, 2000). In turn, high root biomass and high microarthropod biomass are associated with an increase in the mass flows through different channels of the soil food web. These food web interactions are too complex to accurately predict the outcome for overall decomposition and soil organic matter regulation, but some impact cannot be excluded (Siepel and Maaskamp, 1994) and therefore consequences can be expected for all ecosystem services that are associated with soil organic matter. In fact, nearly all soil ecosystem services may be affected, as their provision is associated with soil organic matter.

In both field studies, the soil mites of groups that are relevant for pest regulation, nutrient cycling and soil formation generally increased after the conversion of arable land to grassland. Such results suggest that with increasing age, the soil mite community of extensive grasslands will develop an increasing capacity of performing these ecosystem functions and services. Yet, here we did not directly test the provisioning of these services at the time of sampling. Targeted experiments, testing e.g., biological control potential or decomposition rates in soils in the presence of artificially created mite communities (e.g., Couteaux et al., 1991), will be needed to test the hypotheses raised in this study (Adhikari and Hartemink, 2016). Given the previous results by e.g., Horrocks et al. (2014) showing a potentially long time lag in changes in service provision after a land use change (as well as our biotic data suggesting differences in speed of establishment among functional groups), such experiments should ideally run for equivalently long periods of time.

For grasslands under conservation management, the later stage development of soil mite communities may be accelerated by species introductions through application of topsoil and sods from late-successional stages, in order to optimize the above discussed functions and services. The relevance thereof may, however, change with the converted land use. Thus, pest control as an ecosystem service may be less important for grasslands than it is for arable cropping systems, decreasing in relevance and value with decreasing agricultural use. Likewise, the ecosystem function of nutrient cycling is valued for natural soil fertility in the cropping system, whilst the opposite (nutrient conservation and even immobilization) becomes more desirable under grassland conservation management.

As the development of the soil mite community is boosted upon conversion toward grassland, 1 year or several years of grassland in extended crop rotations may already enhance the provision of these ecosystem services. A conversion back to arable land will likely result in similarly rapid change in mite communities, altering the species composition and reducing both the biomass and number of taxa of the local mite community (e.g., Postma-Blaauw et al., 2012). However, preliminary results for an additional land use treatment at Lusignan, consisting of an 3 years grassland: 3 years arable land rotation, suggest that even after a conversion back to arable land at least part of the diversity is maintained albeit with a much lower biomass (De Groot et al., unpublished data). Thus, for sustainable arable cropping systems aiming at optimizing the provision of ecosystem services it could be worthwhile to widen the rotation to include a certain period of grassland. Longer periods of grassland in the rotation cycle might be preferable, since our chronosequence data suggest that decades of extensive management may be required to reach the full potential to which mites may contribute to service provisioning. Further research, studying changes in mite communities over time in soils subjected to different grassland / arable land rotation schemes, are required to get a full insight in how periods of grassland can be incorporated in crop rotation schemes in such a way that the services contributed by soil mites are maximized. This understanding will help to evaluate and further develop green growth rotation schemes and maintaining permanent grassland as greening practices stimulated under the EU Common Agriculture Policy.

\section{AUTHOR CONTRIBUTIONS}

WD and JF performed the field work, with assistance from XC. WD performed the species identifications and biomass calculations. GD and GJ analyzed the data. GD, GJ, and JF wrote the first version of the manuscript, with input from WD and XC.

\section{FUNDING}

This research was funded by the European Commission through the FP7 project EcoFINDERS (Ecological Function and Biodiversity Indicators in European Soils; www.ecofinders.eu; grant number FP7-264465) and by the strategic research program KBIV "Sustainable spatial development of ecosystems, landscapes, seas and regions" which is funded by the Dutch Ministry of Economic Affairs and carried out by Wageningen University and Research Centre.

\section{ACKNOWLEDGMENTS}

We thank the site managers of the two LTO sites (Veluwe: Prof. Wim van der Putten; SOERE ACBB Lusignan: Abad Chabbi) for providing the opportunity for research and for valuable details on the history of the sites. We thank Prof. Henk Siepel for his advice on a proper calculation of mite biomasses.

\section{SUPPLEMENTARY MATERIAL}

The Supplementary Material for this article can be found online at: http://journal.frontiersin.org/article/10.3389/fenvs. 2016.00015 


\section{REFERENCES}

Adhikari, K., and Hartemink, A. E. (2016). Linking soils to ecosystem services - a global review. Geoderma 262, 101-111. doi: 10.1016/j.geoderma.2015.08.009

Afifi, A., and Van der Geest, L. P. S. (1984). "Notes on the development and biology of the predacious soil mite Cosmolaelaps claviger (Berlese 1883) Gamasida: Laelapidae," in Acarology VI, eds D. A. Griffiths and C. E. Bowman (Chichester: E. Horwood), 585-591.

Bardgett, R. D., and Shine, A. (1999). Linkages between plant litter diversity, soil microbial biomass and ecosystem function in temperate grassland. Soil Biol. Biochem. 31, 317-321. doi: 10.1016/S0038-0717(98)00121-7

Barrios, E. (2007). Soil biota, ecosystem services and land productivity. Ecol. Econ. 64, 269-285. doi: 10.1016/j.ecolecon.2007.03.004

Bennison, J., Maulden, K., and Maher, H. (2002). Choice of predatory mites for biological control of ground-dwelling stages of western flower thrips within a 'push-pull' strategy on pot chrysanthemum. IOBC/WPRS Bull 25, 9-12.

Bhattacharyya, S. (1962). Laboratory studies on the feeding habits and life cycles of soil-inhabiting mites. Pedobiologia 1, 291-298.

Bruin, J., van der Geest, L. P. S., and Sabelis, M. W. (1999). "Ecology and evolution of the acari," in Proceedings of the 3rd Symposium of the European Association of Acarologists 1996 (Amsterdam: Springer).

Brussaard, L., De Ruiter, P. C., and Brown, G. G. (2007). Soil biodiversity for agricultural sustainability. Agric. Ecosys. Environ. 121, 233-244. doi: 10.1016/j.agee.2006.12.013

Buckley, D. H., and Schmidt, T. M. (2001). The structure of microbial communities in soil and the lasting impact of cultivation. Microb. Ecol. 41, 11-21. doi: $10.1007 / \mathrm{s} 002480000108$

Cortet, J., Gillon, D., Joffre, R., Ourcival, J.-M., and Poinsot-Balaguer, N. (2002). Effects of pesticides on organic matter recycling and microarthropods in a maize field: use and discussion of the litterbag methodology. Eur. J. Soil Biol. 38, 261-265 doi: 10.1016/S1164-5563(02)01156-1

Couteaux, M. M., Mousseau, M., Celerier, M. L., and Bottner, P. (1991). Increased Atmospheric $\mathrm{CO} 2$ and litter quality - decomposition of sweet chestnut leaf litter with animal food webs of different complexities. Oikos 61, 54-64. doi: $10.2307 / 3545406$

Culliney, T. W. (2013). Role of arthropods in maintaining soil fertility. Agriculture 3, 629-659. doi: 10.3390/agriculture3040629

Curry, J. P. (1969). The decomposition of organic matter in soil. Part II. The fauna of decaying grassland herbage. Soil Biol. Biochem. 1, 259-266. doi: 10.1016/0038-0717(69)90008-X

De Vries, F. T., Thébault, E., Liiri, M., Birkhofer, K., Tsiafouli, M. A., and Bjørnlund, L. (2013). Soil food web properties explain ecosystem services across European land use systems. Proc. Natl. Acad. Sci. U.S.A. 110, 14296-14301. doi: 10.1073/pnas. 1305198110

Dirilgen, T., Arroyo, J., Dimmers, W. J., Faber, J. H., Stone, D., Da Silva, P. M., et al. (2015). Mite community composition across a European transect and its relationships to variation in other components of soil biodiversity. Appl. Soil Ecol. 97, 86-97. doi: 10.1016/j.apsoil.2015. 06.008

Duchicela, J., Sullivan, T. S., Bontti, E., and Bever, J. D. (2013). Soil aggregate stability increase is strongly related to fungal community succession along an abandoned agricultural field chronosequence in the Bolivian Altiplano. J. Appl. Ecol. 50, 1266-1273. doi: 10.1111/1365-2664. 12130

Duru, M., Theau, J. P., and Martin, G. (2015). A methodological framework to facilitate analysis of ecosystem services provided by grassland-based livestock systems. Int. J. Biodivers. Sci. Manage. 11, 128-144. doi: 10.1080/21513732.2015. 1030695

El Titi, A. (1984). Auswirkung der Bodenbearbeitungsart auf die edaphischen Raubmilben. Pedobiologia 27, 79-88.

Foley, J. A., Defries, R., Asner, G. P., Barford, C., Bonan, G., Carpenter, S. R., et al. (2005). Global consequences of land use. Science 309, 570-574. doi: $10.1126 /$ science. 1111772

Freckman, W. D., Blackburn, T. H., Brussaard, L., Hutchings, P., Palmer, M. A., and Snelgrove, P. V. R. (1997). Linking Biodiversity and Ecosystem Functioning of Soils and Sediments. Ambio 26, 556-562.

Gerson, U., Smiley, R. L., and Ochoa, R. (2003). Mites (Acari) for Pest Control. Hoboken: John Wiley and Sons.
Giller, K. E., Beare, M. H., Lavelle, P., Izac, A. M. N., and Swift, M. J. (1997). Agricultural intensification, soil biodiversity and agro ecosystem function. Appl. Soil. Ecol. 6, 3-16. doi: 10.1016/S0929-1393(96)00149-7

Gil-Martín, J., and Subias, L. S. (1998). Estudio faunístico de los Oribátidos (Acari, Oribatida) de pinares incendiados de un sector de la cara Sur de la Sierra de Gredos (Avila). Boln. Asoc. Esp. Ent. 22, 185-210.

Hågvar, S., and Kjøndal, B. R. (1981). Succession, diversity and feeding habits of microarthropods in decomposing birch leaves. Pedobiologia 22, 385-408.

Haines-Young, R., and Potschin, M. (2013). Common International Classification of Ecosystem Services (CICES): Consultation on Version 4, August-December 2012. EEA Framework Contract No EEA/IEA/09/003. Nottingham, UK: University of Nottingham.

Hartenstein, R. (1962). Soil Oribatei: I. Feeding specificity among forest soil oribatei. Ann. Ent. Soc. Am. 55, 202-206. doi: 10.1093/aesa/55.2.202

Horrocks, C. A., Dungait, J. A. J., Cardenas, L. M., and Heal, K. V. (2014). Does extensification lead to enhanced provision of ecosystem services from soils in UK agriculture? Land Use Policy 38: 123-128. doi: 10.1016/j.landusepol.2013.10.023

Horrocks, C. A., Heal, K. V., Harvie, B., Tallowin, J. B., Cardenas, L. M., and Dungait, J. A. J. (2016). Can species-rich grasslands be established on former intensively managed arable soils? Agric. Ecosyst. Environ. 217, 59-67. doi: 10.1016/j.agee.2015.10.015

Hughes, A. (1976). The mites of stored food and houses. Techn. Bull. Mini. Agric. Fisher. Food 9, 1-400.

Ingham, E. R. (1985). Review of the effects of 12 selected biocides on target and non-target soil organisms. Crop Protect, 4, 3-32. doi: 10.1016/02612194(85) $90002-X$

INRA Poitou-Charentes (2015). Environmental Research Observation and Experimentation System. Available online at: http://www.poitou-charentes. inra.fr/en/Outils-et-Ressources/Experimental-facilities/SOERE-ACBB-Lusig nan/(key)/2. [Accessed: 16 October, 2015]

ISO (2006). ISO 23611-2. Soil Quality - Sampling of Soil Invertebrates - Part 2: Sampling and Extraction of Micro-Arthropods (Collembola and Acarina). Geneva: ISO.

Ito, Y. (1971). Predation by manure-inhabiting mesostigmatids on some free-living nematodes. Appl. Ent. Zool. 6, 51-56.

Jagers op Akkerhuis, G. A. J. M., Dimmers, W. J., Van Vliet, P. C. J., Goedhart, P. W., Martakis, G. F. P., and De Goede, R. G. M. (2008). Evaluating the use of gel-based sub-sampling for assessing responses of terrestrial microarthropods (Collembola and Acari) to different slurry applications and organic matter contents. Appl. Soil Ecol. 38, 239-248. doi: 10.1016/j.apsoil.2007. 10.018

Jamshidian, M. K., Akrami, M. A., and Saboori, A. (2015). Oppiid mites (Acari: Oribatida: Oppiidae) from Alborz Province, with a key to the known species and new records for Iran. Pers. J. Acarol. 4, 11-26.

Jones, C. G., Lawton, J. H., and Shachak, M. (1994). Organisms as ecosystem engineers. Oikos 69, 373-386. doi: 10.2307/3545850

Kardol, P., Newton, J. S., Bezemer, T. M., Maraun, M., and Van der Putten, W. H. (2009). Contrasting diversity patterns of soil mites and nematodes in secondary succession. Acta Oecol. 35, 603-609. doi: 10.1016/j.actao.2009.05.006

Karg, W. (1962). "Über die Beziehungen von Edaphishen Raubmilben zur Arthropoden- und Nematodenfauna des Bodens," in Tagungsberichte $n r$. 45, Bericht über die 9 Wanderversammlung Deutscher Entomologen, ed H. Sachtleben (Berlin: Deutsche Akademie), 311-327.

Karg, W. (1989). Acari (Acarina), Milben, Unterordnung Parasitiformes (Anactinochaeta), Uropodina Kramer. SCHILDKROETENMILBEN. Die Tierwelt Deutchlands, Teil 67. Jena; Stuttgart; New York, NY: Gustav Fischer Verlag.

Karg, W. (1993). Acari (Acarina), Milben, Parasitiformes (Anactinochaeta), Cohors Gamasina Leach. RAUBMILBEN. Die Tierwelt Deutchlands, Teil 59. Jena; Stuttgart; New York, NY: Gustav Fischer Verlag.

Klimek, A., and Rolbieki, S. (2014). Moss mites (Acari: Oribatida) in soil revitalizing: a change for practical application in silviculture. Biol. Lett. 51, 71-82. doi: 10.1515/biolet-2015-0007

Koehler, H. (1999). Predatory mites (Gamasina, Mesostigmata). Agric. Ecosys. Environ. 74, 395-410. doi: 10.1016/S0167-8809(99)00045-6

Krantz, G. W., and Walter, D. E. (2009). A manual of Acarology, 3rd Edn. Lubbock: Texas Tech University Press. 
Kremen, C.,Miles, A. (2012). Ecosystem services in biologically diversified versus conventional farming systems: benefits, externalities, and trade-offs. Ecol. Soci. 17, 40. doi: 10.5751/es-05035-170440

Lavelle, P., Decaëns, T., Aubert, M., Barot, S., Blouin, M., Bureau, F., et al. (2006). Soil invertebrates and ecosystem services. Eur. J. Soil Biol. 42 (Suppl. 1), 3-15. doi: 10.1016/j.ejsobi.2006.10.002

Luxton, M. (1972). Studies on the oribatid mites of a Danish beechwood soil; 1 Nutritional biology. Pedobiologia 12, 434-466.

Luxton, M. (1982). Substrate utilization by the soil fauna. Oikos 39, 340-341.

Madej, G., and Stodółka, A. (2008). Successional changes and diversity of mesostigmatid mite communities (Acari: Mesostigmata) on reclaimed power plant waste dumps. Ann. Zool. 58, 267-278. doi: 10.3161/000345408X326582

Maraun, M., and Scheu, S. (2000). The structure of oribatid mite communities (Acari, Oribatida): patterns, mechanisms and implications for future research. Ecography 23, 374-383 doi: 10.1111/j.1600-0587.2000.tb00294.x

McCune, B., and Mefford, M. J. (1999). PC-ORD. Multivariate Analysis of Ecological Data. Version 5.0. Oregon: MjM Software.

Menta, C., Leoni, A., Gardi, C., and Conti, F. D. (2011). Are grasslands important habitaits for soil microarthropod conservation? Biodiv. Cons. 20, 1073-1087. doi: 10.1007/s10531-011-0017-0

Menzler-Hokkanen, I. (2006). "Socioeconomic significance of biological control," in An Ecological and Societal Approach to Biological Control, eds J. Eilenberg and H. M. T. Hokkanen (Dordrecht: Springer), 13-25. doi: 10.1007/978-1-40204401-4_2

Millennium Ecosystem Assessment Panel (2005). Ecosystems and Human Wellbeing: Synthesis. Washington, DC: Island Press.

Minor, M. A., and Cianciolo, J. M. (2007). Diversity of soil mites (Acari: Oribatida, Mesostigmata) along a gradient of land use types in New York. Appl. Soil. Ecol. 35, 140-153. doi: 10.1016/j.apsoil.2006.05.004

Moore, J. C., and De Ruiter, P. C. (2000). "Invertebrates in detrital food webs along gradients of productivity," in Invertebrates as Webmasters in Ecosystems, eds D. C. Coleman and P. F. Hendrix (Wallingford: CABI Publishing), 161-184.

Murvanidze, M., and Weigmann, G. (2003). Contribution to the Oribatid Mite Fauna of Georgia. 1. New species of Poronota (Acari, Oribatida). Spixiana 26, 165-170.

Neutel, A.-M. (2001). Stability of Complex Food Webs, Pyramids of Biomass, Interaction Strengths and the Weight of Trophic Loops. PhD thesis. Utrecht: Utrecht University.

Petersen, H., and Luxton, M. (1982). A comparative analysis of soil fauna populations and their role in decomposition processes. Oikos 39, 288-388. doi: $10.2307 / 3544689$

Postma-Blaauw, M. B., De Goede, R. G. M., Bloem, J., Faber, J. H., and Brussaard, L. (2010). Soil biota community structure and abundance under agricultural intensification and extensification. Ecology 91, 460-473. doi: 10.1890/09-0666.1

Postma-Blaauw, M. B., De Goede, R. G. M., Bloem, J., Faber, J. H., and Brussaard, L. (2012). Agricultural intensification and de-intensification differentially affect taxonomic diversity of predatory mites, earthworms, enchytraeids, nematodes and bacteria. Appl. Soil Ecol. 57, 39-49. doi: 10.1016/j.apsoil.2012.02.011

Scheu, S., and Schulz, E. (1996). Secondary succession, soil formation and development of a diverse community of oribatids and saprophagous soil macro-invertebrates. Biodiv. Cons. 5, 235-250. doi: 10.1007/BF00055833

Seastedt, T. (1984). The role of microarthropods in decomposition and mineralization processes. Ann. Rev. Entom. 29, 25-45. doi: 10.1146/annurev.en.29.010184.000325

Siepel, H. (1991). "Recovering of natural processes in abandoned agricultural areas: decomposition of organic matter," in Proceedings 4th ECE/XIII SIEEC (Gödöllö), 374-379.

Siepel, H. (1994). Life-history tactics of soil microarthropods. Biol. Fert. Soil. 18, 263-278. doi: 10.1007/BF00570628
Siepel, H. (1996). Biodiversity of soil microarthropods: the filtering of species. Biodiv. Cons. 5, 251-260. doi: 10.1007/BF00055834

Siepel, H., and De Ruyter-Dijkman, E. (1993). Feeding guilds of oribatid mites based on their carbohydrase activities. Soil Biol. Biochem. 25, 1491-1497. doi: 10.1016/0038-0717(93)90004-U

Siepel, H., and Maaskamp, F. (1994). Mites of different feeding guilds affect decomposition of organic matter. Soil Biol. Biochem. 26, 1389-1394. doi: 10.1016/0038-0717(94)90222-4

Siepel, H., and Van de Bund, C. F. (1988). The influence of management practices on the microarthropod community of grassland. Pedobiologia 31, 339-354.

Simsek, N., and Baran, S. (2012). First Record of Amerobelba decedens Berlese 1908 (Acari: Oribatida: Amerobelbidae) from Turkey. Cankaya Univ. J. Science. Engin. 9, 117-123.

Snyder, W. E., and Straub, C. S. (2005). "Exploring the relationship among predator diversity, intraguild predation, and effective biological control," in Proceedings of the Second International Symposium on Biological Control of Arthropods 1 (Davos), 472-479.

Straub, I. (2006). Exploring the Relationship between Natural Enemy Biodiversity and Herbivore Suppression. PhD Thesis. Washington, DC: Washington State University.

Swift, M. W., Heal, O. W., and Anderson, J. M. (1979). Decomposition in Terrestrial Ecosystems. Berkeley, CA: University of California Press.

Tsiafouli, M. A., Thébault, E., Sgardelis, S. P., De Ruiter, P. C., Van der Putten, W. H., Birkhofer, K., et al. (2015). Intensive agriculture reduces soil biodiversity across Europe. Glob. Chang. Biol. 21, 973-985. doi: 10.1111/gcb. 12752

Van Capelle, C., Schrader, S., and Brunotte, J. (2012). Tillage-induced changes in the functional diversity of soil biota - A review with a focus on German data. Eur. J. Soil Biol. 50, 165-181. doi: 10.1016/j.ejsobi.2012.02.005

Van der Wal, A., van Veen, J. A., Smant, W., Boschker, H. T. S., Bloem, J., Kardol, P., et al. (2006). Fungal biomass development in a chronosequence of land abandonment. Soil Biol. Biochem. 38, 51-60. doi: 10.1016/j.soilbio.2005. 04.017

Van Vliet, P. C. J., and Hendrix, P. F. (2007). "Role of fauna in soil physical processes," in Soil Biological Fertility: a key to sustainable land use in agriculture, eds L. K. Abbott and D. V. Murphy (Dordrecht: Springer), 61-80.

Wall, D. H., Bardgett, R. D., and Kelly, E. F. (2010). Biodiversity in the dark. Nat. Geosci. 3, 297-298. doi: 10.1038/ngeo860

Weigmann, G. (2006). Die Tierwelt Deutschlands, 76. Teil Hornmilben (Oribatida). Keltern: Verlag Goecke and Evers.

Wissuwa, J., Salamon, J. A., and Frank, T. (2013). Oribatida (Acari) in grassy arable fallows are more affected by soil properties than habitat age and plant species. Eur. J. Soil Biol. 59, 8-14. doi: 10.1016/j.ejsobi.2013.08.002

Wissuwa, J., Salamon, J.-A., and Frank, T. (2012). Effects of habitat age and plant species on predatory mites (Acari, Mesostigmata) in grassy arable fallows in Eastern Austria. Soil Biol. Biochem. 50, 96-107. doi: 10.1016/j.soilbio.2012.02.025

Conflict of Interest Statement: The authors declare that the research was conducted in the absence of any commercial or financial relationships that could be construed as a potential conflict of interest.

Copyright (c) 2016 de Groot, Jagers op Akkerhuis, Dimmers, Charrier and Faber. This is an open-access article distributed under the terms of the Creative Commons Attribution License (CC BY). The use, distribution or reproduction in other forums is permitted, provided the original author(s) or licensor are credited and that the original publication in this journal is cited, in accordance with accepted academic practice. No use, distribution or reproduction is permitted which does not comply with these terms. 